Egyptian Journal of Aquatic Biology \& Fisheries

Zoology Department, Faculty of Science,

Ain Shams University, Cairo, Egypt.

ISSN $1110-6131$

Vol. 22(5): 587 - 595 (2018)

www.ejabf.journals.ekb.eg

\title{
The possibility to overcome of fish protein gap in Egypt
}

\author{
Saber M.M. ${ }^{1}$; Ahmed, M.Kh ${ }^{1}$, and Ibrahim, S. M. ${ }^{2}$ \\ 1-Economic \& Fish Statistics Lab., National Institute of Oceanography and Fisheries, \\ Cairo, Egypt \\ 2- Fish Processing Technology Lab., National Institute of Oceanography and \\ Fisheries, Cairo, Egypt \\ Corresponding Author: Saber_mostafa0@yahoo.com
}

\section{ARTICLE INFO \\ Article History: \\ Received: Nov. 20, 2018 \\ Accepted: Dec. 27, 2018 \\ Online: Dec. 30, 2018}

\section{Keywords:}

Fish production

Fish consumption

National income

Egypt

Fish protein gap

self-sufficiency

\begin{abstract}
Fish is one of the main resources of relatively cheap animal protein and Egyptian national income. Although Egypt has a large aquatic area but there is a fish protein gap, where the average per capita is lower compared to some developed countries. Therefore, the current study investigate the main reasons caused this gap during periods 1995-2015. Analysis of the factors associated with this gap and forecasting of its future status, the linear regression and Box and Jenkins method were used. The data showed that the cash value of fish recorded 23.4 billion pounds $(19.6 \%$ of animal production) during 2015 (GAFRD, 2016). The average per capita was 18.2 kglyear compared with $70 \mathrm{~kg}$ in Japan, 35.4 in East Asia, 33.4 in Southeast Asia, and 35.1 in China during the same period. The annual growth rate of fish produced in Egypt was 3\%, while it was $4.2 \%$ of consumption rate. The variation between production and consumption (276.3 thousand tones) led to a shortage in the self-sufficiency. In conclusion, this study recommends a future strategy for fish production to optimal exploit of all aquatic resources to reach self-sufficiency, processing and exporting.
\end{abstract}

\section{INTRODUCTION}

Food security is an important issue should be interested by policy makers in Egypt where providing food is a political rather than an economic order and it is one of the indicators of successfully economic and social policies (Shata, 2014). Fish production sector is considered one of the sectors which contribute in self-sufficiency of animal protein where fish contain the most important nutrients that must be available in human food. In addition to it is the basic economic activity in the national economy especially in the animal and agricultural sectors (Elabd et al., 2012). The cash value of fish sector was about 2.1 billion pounds in 1995 , while it reached 23.4 billion pounds in 2015 (GAFRD, 2016). Egypt is suffering from deficiencies of the different protein sources and the diseases of the livestock sector and the higher price levels of red meat and poultry increased of this gap. Therefore, the study problem is the rate of fish consumption more than fish production. Besides, several studies have been reported that about 5.2 million tons during 1995- 2015 contributed about $45 \%$ of the local consumption (Saber et al., 2008). In general, the self-sufficiency issue of fish protein is very important to overcome of fish protein 
gap. Therefore, the current study aims to analyze the current and future status of the fish gap in Egypt to design a future strategy to overcome of fish protein deficiency.

\section{MATERIALS AND METHODS}

\section{Materials}

Published and unpublished data set by Food and Agriculture Organization (FAO, 2014), WHO (2014), Central Agency for Public Mobilization and Statistics (CAPMAS, 2016), Fish Production Bulletin, various issues, period (1995-2015); Ministry of Agriculture and Land Reclamation, General Authority for Fisheries Development, Fish Production Statistics (1995-2015) and some websites related to the fish gap.

\section{Statistical methods}

The multiple regression analysis, the presentation of the best economically and statistically acceptable mathematical images, and Box and Jenkins method (1976) were applied. The models of the variables; the time series plot, the partial and subjective correlation function before and after stability, and the prediction of future values using some mathematical programs (Minitab and SPSS) were measured. To identify the factors affecting the fish gap and then assume that the gap (y) is a factor in both the local production $\mathrm{x} 1$ and the available consumption $\mathrm{x} 2$, the average share of $x 3$, the number of population $x 4$, the quantity of exports $x 5$, the quantity of imports $\mathrm{x} 6$ and the quantity of production coverage for consumption $\mathrm{x} 7$ as independent variables using the linear and logarithmic models, and after excluding the variables that did not prove their significance, it was found that the best of these formulas in terms of economic and statistical equations are:

Logy $=-0.109+1.02 \log \times 6-.03 \log \times 5$

$$
\begin{aligned}
& (-2.77) \quad(133.5) \\
& \mathrm{F}=(1.16) \mathrm{R}^{2}=(99)
\end{aligned}
$$

Where the estimated relationship indicated that fish imports and exports $\mathrm{x} 6, \mathrm{x} 5$ are the two factors.

\section{RESULTS AND DISCUSSION}

\section{Egyptian fish sector and its importance}

When studying the current status of the Egyptian fish sector and its contribution to achieving self-sufficiency of fish during the period 1995-2015, it was observed that it contributes about 23.4 billion pounds i.e. $7.3 \%$ of the total national agricultural income estimated at 318.3 billion pounds. The average contribution of capture fisheries during the year 2015 was about 344.1 thousand tons (LE 6.3 billion of the total value of Egyptian fish production as reported by CAPMAS (2016).

\section{Factors associated with fish gap}

Several variables are associated with the fish gap in Egypt during the period (1995 - 2015) such as population, average consumption, per capita, production, and fish trade can be identified as shown in Table (1). Population was characterized by a continuous increase of 57.6 million in 1995 (63.4 million as an average for the period 1995-2004). While during 2015, it reached 88.9 million i.e. 79 million as average during the period 2005-2015 and 71.6 million as general average. The annual growth rate is estimated at about $1.5 \%$ as mentioned by CAPMAS (2016). Concerning to local fish production, Table (1) shows that the average quantities of fish produced were 955 thousand tons during the period 1995 - 2015 and 407 thousand tons, a 
minimum quantity during 1995. While the maximum was 1.5 million tons in 2015 and the rate of change was 5.9\%. From the equation (1) (Table, 2), it could be observed that the quantity of fish production increased where the annual growth rate estimated by $6.5 \%$. The statistical significance of the regression coefficient $(0.01$ and $95 \%$ ) proved that this increment is due to the factors of time as exhibited $\mathrm{F}$ value used in the models.

Table 1: Fish balance in A.R.E. during the period (1995 - 2015), production per thousand tons - $\mathrm{m} /$ per capita $\mathrm{kg}$.

\begin{tabular}{|c|c|c|c|c|c|c|c|c|c|}
\hline \multirow[b]{2}{*}{ Bulletin } & \multirow[b]{2}{*}{ Population } & \multirow{2}{*}{$\begin{array}{c}\text { Local } \\
\text { production }\end{array}$} & \multicolumn{2}{|c|}{ Foreign Trade } & \multirow{2}{*}{$\begin{array}{l}\text { Available for } \\
\text { consumption }\end{array}$} & \multirow{2}{*}{$\begin{array}{c}\text { Per } \\
\text { capita }\end{array}$} & \multirow[b]{2}{*}{ Fish gap } & \multirow{2}{*}{$\begin{array}{c}\% \text { Self- } \\
\text { sufficiency }\end{array}$} & \multirow{2}{*}{$\begin{array}{l}\text { Production } \\
\text { coverage } \\
\text { for } \\
\text { consumpti } \\
\text { on \day }\end{array}$} \\
\hline & & & Imports & Exports & & & & & \\
\hline 1995 & 57.62 & 407 & 141.74 & 0.93 & 547.8 & 9.51 & 140.8 & 74.3 & 272 \\
\hline 1996 & 58.85 & 432 & 144.11 & 0.58 & 575.5 & 9.78 & 143.5 & 75.1 & 275 \\
\hline 1997 & 60.03 & 457 & 207.36 & 2.23 & 662.1 & 11.03 & 205.1 & 69 & 253 \\
\hline 1998 & 61.35 & 546 & 176.3 & 2.14 & 720.2 & 11.74 & 174.2 & 75.8 & 277 \\
\hline 1999 & 62.65 & 649 & 193.16 & 0.69 & 841.5 & 13.43 & 192.5 & 77.1 & 282 \\
\hline 2000 & 63.97 & 724 & 213.63 & 0.96 & 936.7 & 14.64 & 212.7 & 77.3 & 283 \\
\hline 2001 & 65.27 & 772 & 261.43 & 1.22 & 1032.2 & 15.81 & 260.2 & 74.8 & 274 \\
\hline 2002 & 66.51 & 803 & 154.39 & 2.56 & 954.8 & 14.36 & 151.8 & 84.1 & 308 \\
\hline 2003 & 67.97 & 876 & 163.01 & 3.13 & 1035.9 & 15.24 & 159.9 & 84.6 & 310 \\
\hline 2004 & 69.33 & 865 & 220.82 & 1.91 & 1083.9 & 15.63 & 218.9 & 79.8 & 292 \\
\hline $\begin{array}{l}\text { Period } \\
\text { average }\end{array}$ & 63.36 & 653.10 & 187.60 & 1.64 & 839.06 & 13.12 & 185.96 & 77.19 & 283 \\
\hline 2005 & 70.69 & 889 & 188.52 & 5.13 & 1072.4 & 15.17 & 183.4 & 82.9 & 303 \\
\hline 2006 & 72.01 & 972 & 207.56 & 4.05 & 1175.5 & 16.32 & 203.5 & 82.7 & 303 \\
\hline 2007 & 73.61 & 1008 & 258.93 & 4.42 & 1262.5 & 17.15 & 254.5 & 79.8 & 292 \\
\hline 2008 & 75.1 & 1068 & 136.8 & 6.73 & 1198.1 & 15.95 & 130.1 & 89.1 & 326 \\
\hline 2009 & 76.82 & 1093 & 135.5 & 7.59 & 1220.9 & 15.89 & 127.9 & 89.5 & 328 \\
\hline 2010 & 78.73 & 1305 & 256.81 & 10.6 & 1551.2 & 19.7 & 246.2 & 84.1 & 308 \\
\hline 2011 & 80.41 & 1362 & 182.22 & 9.49 & 1534.7 & 19.09 & 172.7 & 88.7 & 325 \\
\hline 2012 & 82.54 & 1372 & 335.02 & 15.81 & 1691.2 & 20.49 & 319.2 & 81.1 & 297 \\
\hline 2013 & 84.63 & 1454 & 235.85 & 20.45 & 1669.4 & 19.73 & 215.4 & 87.1 & 319 \\
\hline 2014 & 86.81 & 1482 & 584 & 28 & 2038 & 23.48 & 556 & 72.7 & 266 \\
\hline 2015 & 88.96 & 1519 & 296 & 19.7 & 1795.3 & 20.18 & 276.3 & 84.6 & 310 \\
\hline $\begin{array}{c}\text { Period } \\
\text { average }\end{array}$ & 79.12 & 1229.45 & 256.11 & 12.00 & 1473.56 & 18.47 & 244.11 & 83.85 & 307 \\
\hline $\begin{array}{l}\text { General } \\
\text { average }\end{array}$ & 71.61 & 955 & 223.48 & 7.06 & 1171.42 & 15.92 & 216.42 & 80.68 & 295.3 \\
\hline
\end{tabular}

Source:

Central Agency for Public Mobilization and Statistics (CAPMAS, 2016), Fish Production Bulletin, various issues, period (1995-2015); Ministry of Agriculture and Land Reclamation, General Authority for Fisheries Development, Fish Production Statistics (1995-2015).

Table 2: Statistical analysis of half - logarithmic development of the Egyptian fish balance during the period $(1995-2015)$.

\begin{tabular}{|c|c|c|c|c|c|c|c|}
\hline Bulletin & Item & $\begin{array}{l}\text { For non- } \\
\text { average }\end{array}$ & $\begin{array}{c}\text { Annual } \\
\text { growth rate }\end{array}$ & $\begin{array}{l}\text { Factor } \\
\text { D.w }\end{array}$ & $\mathbf{F}$ & $\mathbf{R}^{2}$ & Equation \\
\hline 1 & $\begin{array}{l}\text { Local } \\
\text { production }\end{array}$ & 5.9 & 6.5 & 0.41 & 429.9 & 0.95 & $\begin{array}{c}\log \mathrm{Y}_{\mathrm{t}}=6.07+0.0649 \mathrm{X}_{\mathrm{t}} \\
(20.7)^{* *}(154.4)\end{array}$ \\
\hline 2 & Fish imports & 5.5 & 3.1 & 1.99 & 8.37 & 0.30 & $\begin{array}{c}\log \mathrm{Y}_{\mathrm{t}}=5.00+0.0311 \mathrm{X}_{\mathrm{t}} \\
(2.89)^{*}(37.1) * *\end{array}$ \\
\hline 3 & $\begin{array}{l}\text { Available for } \\
\text { consumption }\end{array}$ & 5.5 & 5.8 & 1.15 & 356.4 & 0.94 & $\begin{array}{c}\log Y_{t}=6.37+0.0579 X_{t} \\
(18.9)^{*}(165.3)\end{array}$ \\
\hline 4 & Fish exports & 15 & 17 & 1.9 & 151.6 & 0.88 & $\begin{array}{c}\log Y_{t}=-0.588+0.177 X_{t} \\
(13.3)^{*}(-3.25)\end{array}$ \\
\hline 5 & M per capita & 3.5 & 3.7 & 1.137 & 142.2 & 0.88 & $\begin{array}{l}\log Y_{t}=2.34+0.0366 X_{t} \\
\quad(11.92)^{* *}(60.7)^{* *}\end{array}$ \\
\hline 6 & Fish gap & 3.5 & 2.8 & 2.044 & 6.29 & 0.24 & $\begin{array}{c}\log \mathrm{Y}_{\mathrm{t}}=5.01+0.275 \mathrm{X}_{\mathrm{t}} \\
(2.51)^{*}(36.4)\end{array}$ \\
\hline 7 & $\begin{array}{l}\% \text { Self- } \\
\text { sufficiency }\end{array}$ & 0.7 & 0.7 & 1.84 & 10.71 & 0.36 & $\begin{array}{c}\log \mathrm{Y}_{\mathrm{t}}=4.31+0.00703 \mathrm{X}_{\mathrm{t}} \\
(3.27)^{* *}(159.8)\end{array}$ \\
\hline 8 & $\begin{array}{l}\text { Coverage } \\
\text { rate }\end{array}$ & 70 & 0.7 & 1.84 & 10.71 & 0.36 & $\begin{array}{c}\log Y_{t}=5.61+0.00705 X_{t} \\
(3.28)^{*}(207.8)\end{array}$ \\
\hline
\end{tabular}

Source: Calculated from Table (1) of the study. ${ }^{*}$ Significant at the potential level of $0.05 \%$. 
Table (1) shows that the minimum fish consumption was 575.5 thousand tons in 1996, while the maximum extent was 2038 thousand tons in 2014, represents $354 \%$ comparing to that of 1995 . The annual average of quantity consumed was 1.2 million tons during the period (1995-2015). Besides, equation (3) (Table 2) shows that the consumption of fish was increased as general trend and the average of annual rate recorded $5.8 \%$ per year with a change $5.5 \%$.

The value of the limiting factor indicated that about $94 \%$ of the changes in the quantity consumed, due to factors reflected by the time factor comparing with the annual growth rate of fish consumption with the same of fish production. In addition, the annual growth rate of production was higher than consumption rate, but the rates of increasing in population were higher than the growth rates and the decline in purchasing behavior due to the increase in prices and also the consequent reduction in consumption rates as shown in Fig. (1).

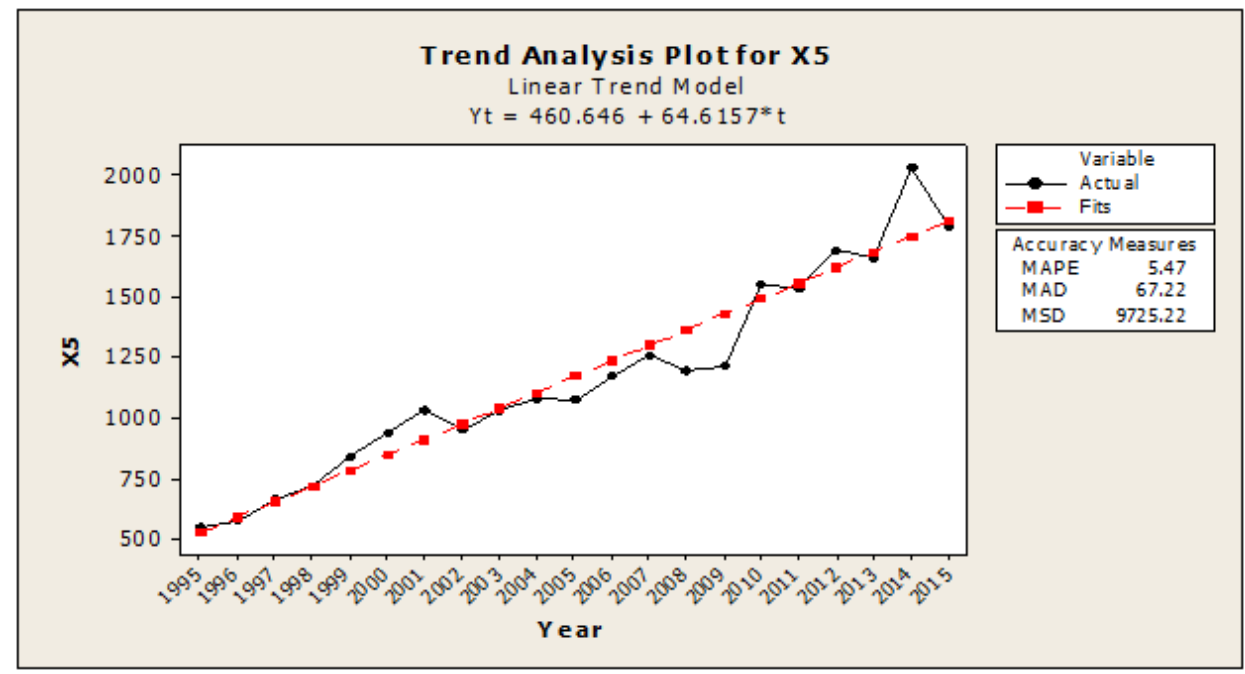

Fig. 1: Available fish consumption during 1995 -2015.

Concerning to foreign fish trade, it could be observed that total quantity of Egyptian fish imports ranged from 141.7 thousand tons in 1995 to 584 thousand tons in 2014, an annual average was 223.5 thousand tons during the period (1995 - 2015). The annual growth rate of increasing was $3.1 \%$ as demonstrated in Table (1). Also, data showed that the regression coefficient was significant $(0.05$ and $30 \%)$ and the change in fish production is due to time factors. On the other hand, the Egyptian fish exports ranged from 0.58 thousand tons in 1996 to 28 thousand tons in 2014. The annual average was 7.1 thousand tons and the rate of change was $15 \%$ during the period 1995 - 2015(Table, 1). Equation (4) (Table, 2) showed that the quantity of Egyptian fish imports was increased and the annual growth rate recorded $17 \%$. The significance (at 0.05 and $88 \%$ ) in fish exports is due to time factors.

With regard to the average of fish per capita, Table (1) exhibits the annual average per capita ranged from $9.5 \mathrm{~kg}$ in 1995 to $23.5 \mathrm{~kg}$ during 2014. The annual average was $15.9 \mathrm{~kg}$ during 1995-2015, a relative increased was observed. Equation (5) in Table (2) indicated that the fish population was upward trend at an annual growth rate of $3.7 \%$. The significance $(0.01$ and $88 \%)$ in average fish per capita was found and due to the time factor. It should be noted that although the annual increased but it did not reach to the minimum recommended (125 grams per day, $45 \mathrm{~kg}$ per year). Or equivalent of $18.4 \%$ of the preventive health limit which negatively affects 
the muscle and mental activity of the individual or consumption of 180 calories of fish according to the daily needs of fish protein in the equivalent of $32 \mathrm{~kg}$ per year (Ahmed, 2010; WHO, 2014 and CAPMAS, 2016).

Data presented in Table (1), it was found that there is a relative stability of selfsufficiency of fish during (1995-2025). Also, Egypt did not reach the stage of fish self-sufficiency despite it has 13.8 million acres as aquatic area. The rate of fish selfsufficiency ranged from a minimum of $69 \%$ in 1997 to a maximum of 89.5 in 2009. An annual average was $80.7 \%$ and the change rate recorded $0.7 \%$. The coefficient indicated that about $36 \%$ of the changes in the fish safety ratio are due to the time factor.

In addition to, Table (1) demonstrates that the longest period of production efficiency for consumption in 2009 was 328 days, while the lowest period in 1996 was 253 days. The average period of production efficiency was 295 days during (1995-2015). The annual increase rate to cover production for local consumption was $7 \%$ according to the logarithmic model in Table (2).

Figure (2) shows the fish gap in Egypt during the period (1995 - 2015). The final outcome of the total needs of fish and its local production reflects gap level. The food gap could be divided into two parts, the virtual gap which is measured between the quantities produced from the product and the local production. On the other hand, the real gap is measured by several measures, including the world average per capita per day in developing countries estimated at 120 grams/person. The fish gap was 216.4 thousand tons during (1995 - 2015), a minimum recorded 127.9 thousand tons during 2009 and a maximum was 556 thousand tons during 2014.

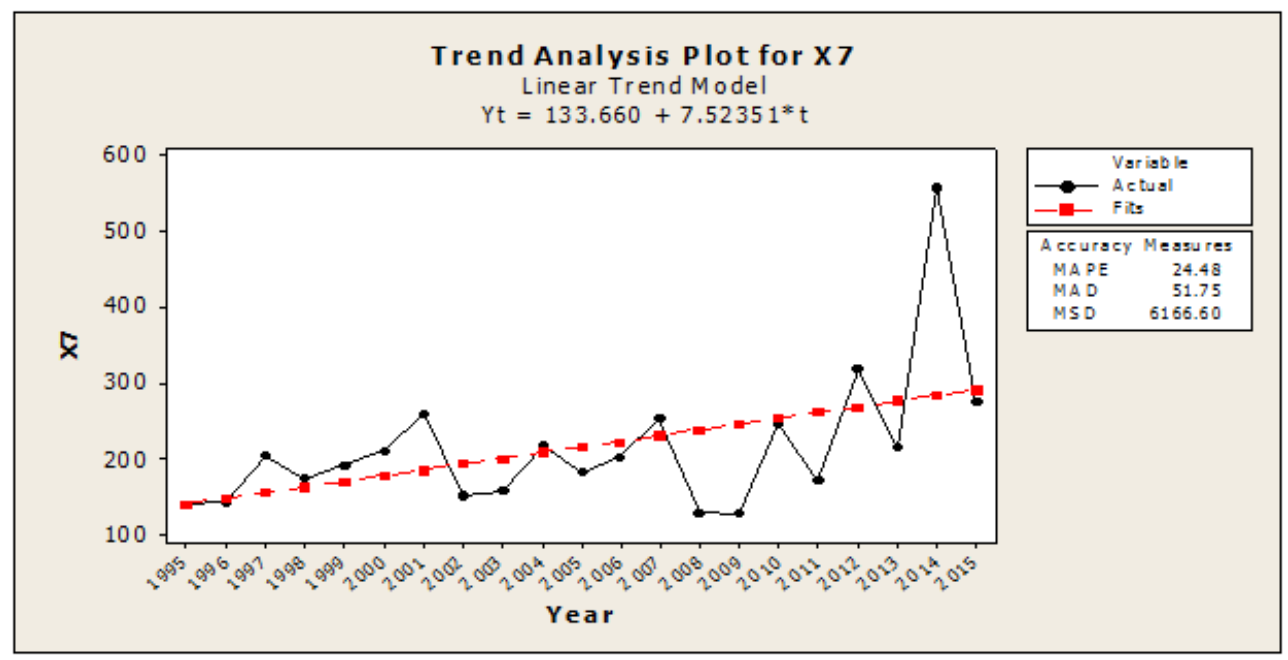

Fig. 2: The fish gap in Egypt during the period (1995 - 2015).

From Table (2), it was found that fish gap increased annually by $2.8 \%$ and the change of annual average reached $3.5 \%$. The coefficient indicated that about $24 \%$ of the changes in the fish gap in Egypt are due to the time factor too. According to international standards, this means that there is a real gap in fish protein. Based on the minimum recommended by WHO (2014), estimated at 120 grams/person of protein per day, the average per capita fish intake should be $43.8 \mathrm{~kg} / \mathrm{day}$. The real and virtual gaps and their impact on the variables of the Egyptian fish balance; the virtual gap of a commodity indicated the adequacy of the quantity produced to meet the local fish consumption. The difference between the quantity produced and available for 
consumption plus imports was calculated. While, the real gap represents the extent of fish production to meet the actual needs of consumers.

The indicators in Table (3) show there is significance between the variables of the fish balance with regard to the average of the Egyptian individual and the average per capita as recommended by WHO (2014). It was found that the average number of fish per capita was $15.9 \mathrm{~kg}$ year, while WHO (2014) recommended the per capita is being 32.9 kglyear (106.7\%) i.e. an increase in consumption reach to 2356.03 thousand tons $(101.12 \%)$. The decrease in the self-sufficiency ratio represents $40.5 \%$ $(8.49 \%)$ and the consequent shortage of production for consumption was 146.9 days from this perspective.

Table 3: Variables of fish scales and values of virtual and real gap in Egypt during the period (1995 2015).

\begin{tabular}{lcccc}
\hline \multirow{2}{*}{ Bulletin $(1995-2015)$} & \multicolumn{3}{c}{ The minimum recommended by WHO (2014) } \\
\cline { 2 - 4 } & $\begin{array}{c}\text { Virtual } \\
\text { values }\end{array}$ & $\begin{array}{c}\text { Real } \\
\text { values }\end{array}$ & $\begin{array}{c}\text { Real } \\
\text { values }\end{array}$ & Rate of change \\
\hline Fish production & 955 & 955 & $\ldots$. & $\ldots .$. \\
Available for consumption & 1171.42 & 2356.03 & 1184.6 & 101.12 \\
M / per capita & 15.9 & 32.9 & 17 & 106.7 \\
Fish gap & 216.42 & 1401.03 & 1184.6 & 547.4 \\
\%Self-sufficiency & 80.7 & 40.5 & 40.2 & 49.8 \\
Production coverage period for & 295.3 & 148.4 & 146.9 & 49.8 \\
consumption & & & & \\
\hline
\end{tabular}

Source: Calculated from table (1) of this study.

The value of the limiting factor at $99 \%$ of the changes in the fish gap is due to these two variables. The signs of independent variables showed the normal of their relationship with the dependent variables. $1 \%$ change in fish imports led to a corresponding change in the gap size at $1.02 \%$, and a $1 \%$ change in fish exports led to a change in the same trend at $0.23 \%$. Fish has been shown a significant model at level of 0.01. The stability of fish balance in Egypt, the values of the difference coefficient reflect the stability of the variables of the fish balance (Table, 3 ). The variable of selfsufficiency percent and the period of production coverage for consumption are more stable than other variables. The difference coefficient was 7.2. The lowest variables were found in local production stability, where the difference coefficient was 13.3. $42.9 \%$ fish is available for consumption and average per capita share is 37.4 and 44.2, respectively (Mohammed, 2012)

Forecasting of the virtual and real fish gaps, the methods of forecasting assume that the factors in the past will continue in the future and this is the tendency of phenomena to recur in the future. Actual results are usually different about estimated or forecasted values. The unpredictability is due to the multiplicity and frequency of variables that affects random factors. Forecasting of fish tends to be more accurate than single or single-fish forecasts, because the forecasting errors are affecting elimination the negative error in the forecasting of a given product or removes the positive error of a second product. The short-term forecasts are more accurate than long-term forecasting, because the first is less likely to be second-guessed (Najm, 2007). So, the future values of the fish gap size are using simple linear regression models and the ARIMA model. The fish gap during the period (2016-2025) was forecasted using the ARIMA model through the indicators present in Table (4) and Figs. $(3,4,5$ and $6 \mathrm{a}, \mathrm{b}, \mathrm{c})$. 
Table 4: The future predictive values of the fish gap in Egypt during the period (2016-2025).

\begin{tabular}{lcccccc}
\hline & \multicolumn{2}{c}{ Gap values using simple linear regression } & \multicolumn{3}{c}{ Gap values using the *ARIMA model } \\
\cline { 2 - 6 } Years & $\begin{array}{c}\text { Forecasting } \\
\text { the size of } \\
\text { the expected } \\
\text { gap }\end{array}$ & $\begin{array}{c}\text { Minimum } \\
\text { forecasting of } \\
\text { gap size }\end{array}$ & $\begin{array}{c}\text { The maximum } \\
\text { limit to } \\
\text { forecasting the } \\
\text { size of the gap }\end{array}$ & $\begin{array}{c}\text { Forecasting } \\
\text { the size of the } \\
\text { gap }\end{array}$ & $\begin{array}{c}\text { Minimum } \\
\text { limits to } \\
\text { forecasting } \\
\text { the size of the } \\
\text { gap }\end{array}$ & $\begin{array}{c}\text { Limits to } \\
\text { forecasting } \\
\text { the size of the } \\
\text { gap }\end{array}$ \\
\hline 2016 & 299178 & 109516 & 488840 & 2.291 & 5.108 & 9.473 \\
2017 & 306701 & 114702 & 498700 & 0.298 & 2.115 & 7.480 \\
2018 & 314225 & 119718 & 508732 & 8.304 & 2.122 & 5.487 \\
2019 & 321748 & 124568 & 518928 & 6.311 & 0.129 & 2.494 \\
2020 & 329272 & 129260 & 529283 & 4.318 & 8.135 & 0.501 \\
2021 & 336795 & 133801 & 539789 & 2.325 & 7.142 & 8.507 \\
2022 & 344319 & 138197 & 550440 & 0.332 & 5.149 & 5.514 \\
2023 & 351842 & 142454 & 561230 & 8.338 & 4.156 & 3.521 \\
2024 & 359366 & 146579 & 572152 & 6.345 & 2.163 & 0.528 \\
2025 & 366889 & 150578 & 583200 & 4.352 & 1.170 & 8.534 \\
\hline
\end{tabular}

*ARIMA models were estimated using the programs (Minitab and SPSS ).

The expected value of the fish gap was 2.291 thousand tons during 2016, a minimum extent was 5.108 thousand tons and a maximum was 9.473 thousand tons during 2016. In 2025, it was estimated 4.352 thousand tons, a minimum of 1.170 thousand tons and a maximum of 8.534 thousand tons. Thereby, the time series model (ARIMA) is more accurate and better because it takes into account the effect of the other variables on the dependent variable compared to the simple linear regression model.

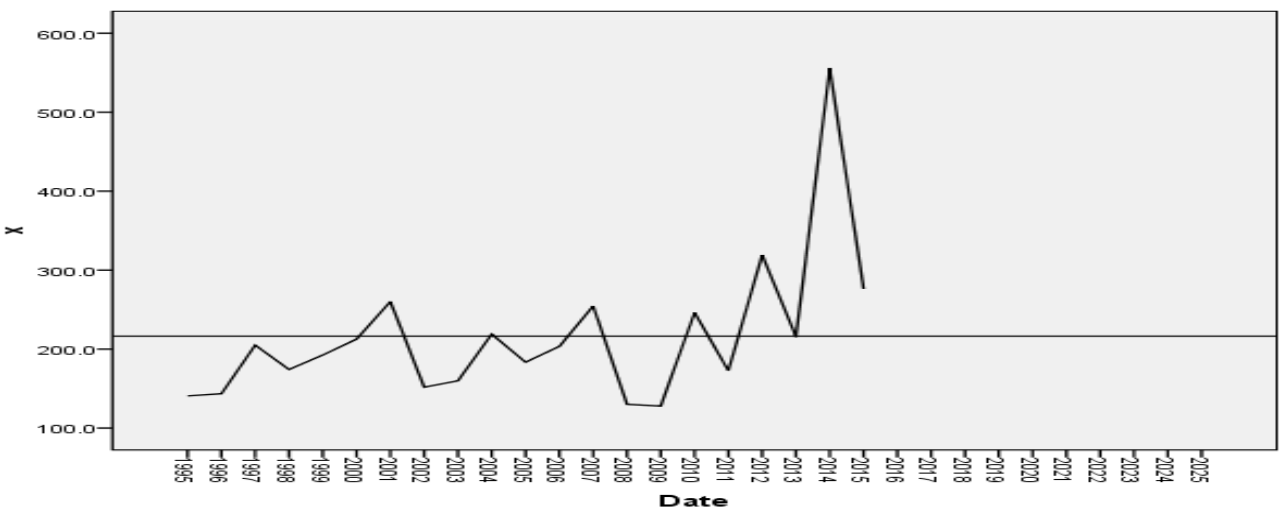

Fig. 3. Identify the time series model.

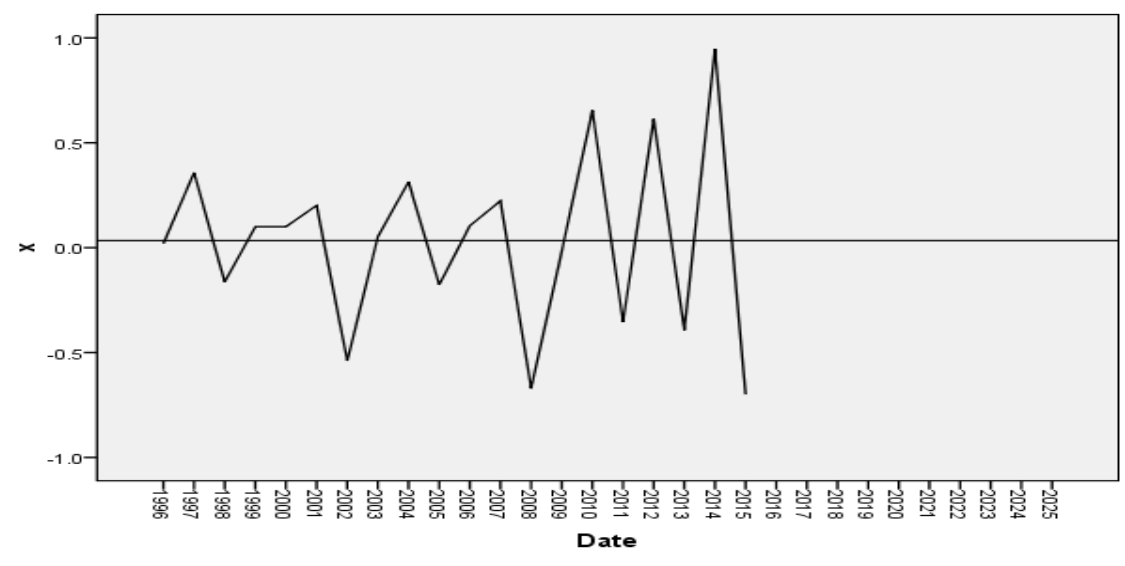

Transforms: natural log, difference(1)

Fig. 4: Time series of stability model. 


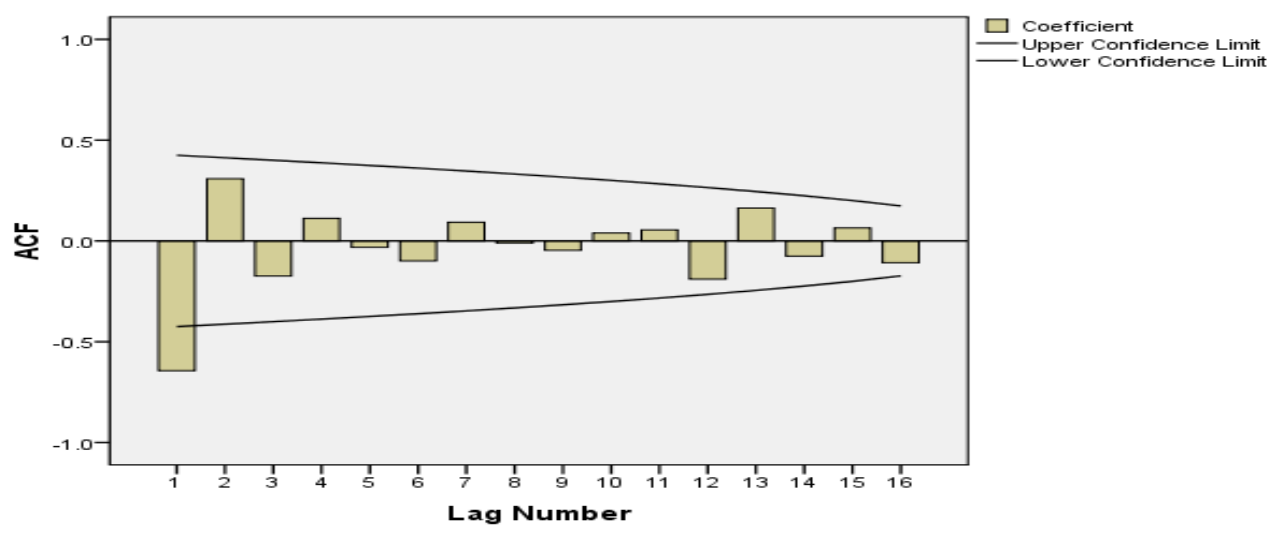

Fig. 5: Estimation of the self-correlation function.

$\mathbf{x}$

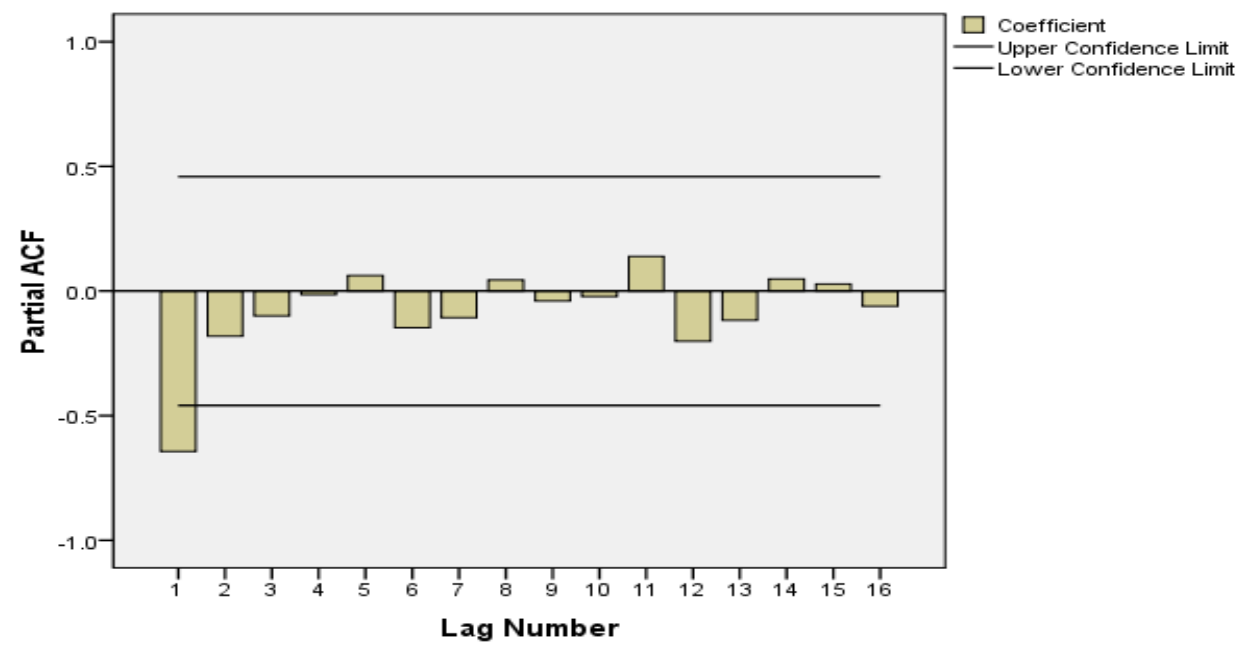

Fig. 6a: Estimation of the partial self - correlation function.

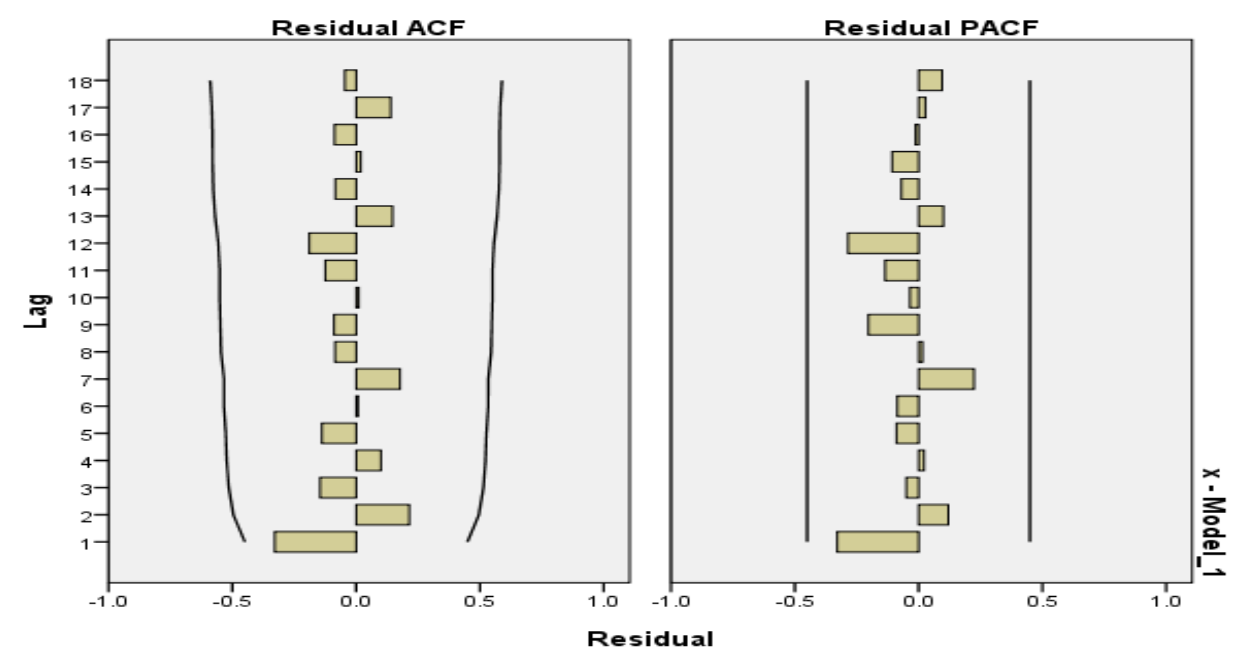

Fig. 6b: Basic series graph, estimated values, and forecasted values. 


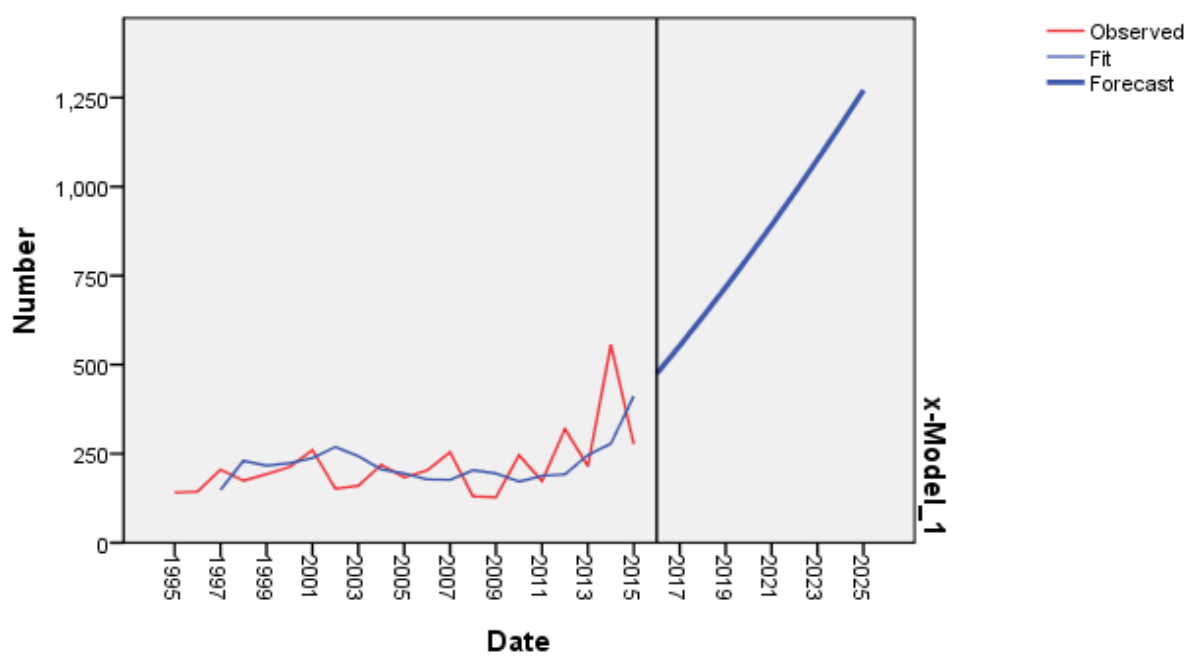

Fig. 6c: Model forecasting phase.

\section{CONCLUSION}

According to the results obtained by ARIMA model, the following orders should be well made; optimal exploitation for all aquatic resources, using the modern methods in aquaculture sector to reach self-sufficiency, processing and exporting.

\section{REFERENCES}

Ahmed A. A. (2010). An attempt to Model and estimate the food gap in Algeria, the Researcher Magazine.pp.20-22.

Box, G. E. P. and G. M. Jenkins (1976). Time Series Analysis: Forecasting and control. Rev. ed. San Francisco: Holden-Day.

Central Agency for Public Mobilization and Statistics (CAPMAS) (1995-2015). Bulletin of Fish Production, Various Issues, period (1995-2015) and National Information Center, unpublished data.

Elabd,W.A.E.; K.I.Ahmed and T. M. Elsantrecy (2012). Analytical study of the food and their determinants. Agri. Economic Research instit. Agric. Econom. and Social Sci., Mansoura Univ., 3 (6): 959 - 970.

FAO (2014). Status of Fisheries and Aquaculture in the World - Opportunities and Challenges - Food and Agriculture Organization of the United Nations, Rome.

Ministry of Higher Education and Scientific Research (2015). National Strategy for Science, Technology and Innovation 2015-2030 together, Fourth Axis "Food and Agriculture", Cairo, Egypt.

Mohammed, S. (2012). Methods of standard economic: Lectures and Applications. Dar Al-Hamed for Publication and Distribution, Amman, Jordan.

Najm A. N. (2007). Introduction to the management of operations. Amman: Dar AlManaheg for Publishing and Distribution.

Saber, M.M.; G.E. Azazy ; W.A.E. El-Abd and Abeer B.M. Khalil (2008). Role of fishes in development of the animal production for meeting the effects resultant from Bird Flu. Egypt. J. of Appl. Sci., 23 (2B):604 - 623.

Shata, A. M. (2014). An economic analysis of the food gap of red meat in Egypt. J. Agric. Econom. and Social Sci., Mansoura Univ., Vol.5(2), February, 2014.

Soliman, O. R. A. (2007). Statistical Analysis of Data Using SPSS, Department of Statistics and Mathematics, Faculty of Commerce, Menoufia University. 